
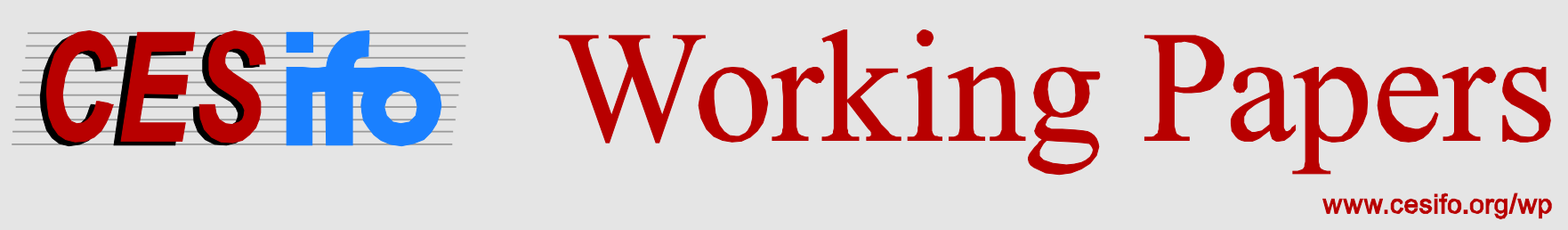

\title{
Regional Heterogeneity, the Rise of Public Debt and Monetary Policy in Post-Bubble Japan: Lessons for the EMU
}

\author{
Raphael Fischer \\ Gunther Schnabl
}

\author{
CESIFO WORKING PAPER NO. 5908 \\ CATEgory 6: FisCAL Policy, MaCroeconomics AND GROWTH \\ MAY 2016
}

An electronic version of the paper may be downloaded

- from the SSRN website: Www.SSRN.com

- from the RePEc website: Www.RePEc.org

- from the CESifo website: www.CESifo-group.org/wp 


\title{
Regional Heterogeneity, the Rise of Public Debt and Monetary Policy in Post-Bubble Japan: Lessons for the EMU
}

\begin{abstract}
Both Japan and parts of the European Monetary Union have experienced boom and bust in stock and real estate markets, which have been followed by a lasting crisis. The paper analyses the role of a high degree of regional heterogeneity for public debt and monetary policy in the context of crisis. It is shown for Japan that the attempts to maintain regional cohesion via a regional transfer mechanism has contributed to the unprecedented rise in public debt and persistent monetary expansion. Econometric estimations show that in Japan regional redistribution of funds has ensured homogeneous living conditions across Japanese regions preand post-crisis. The side condition is monetary expansion. A similar effect could emerge in Europe, if the crisis persists.
\end{abstract}

JEL-Codes: H120, H770, E520.

Keywords: Japan, EMU, crisis, regional redistribution, monetary policy, public debt.

\author{
Raphael Fischer \\ Leipzig University \\ Institute for Economic Policy \\ Grimmaische Str. 12 \\ Germany - 04109 Leipzig \\ ra.fischer@wifa.uni-leipzig.de
}

\author{
Gunther Schnabl \\ Leipzig University \\ Institute for Economic Policy \\ Grimmaische Str. 12 \\ Germany - 04109 Leipzig \\ schnabl@wifa.uni-leipzig.de
}

We thank Taiki Murai for the outstanding research assistance and the participants of the 2015 EEFS Conference for useful comments. 


\section{Introduction}

The bursting of the Japanese bubble economy in December 1989 marks the starting point of a lingering crisis (Figure 1), which has been characterized as (more than) two lost decades (see for instance Hayashi and Prescott 2002). The lasting stagnation, which has been accompanied by prime interest rates cuts towards zero and an unprecedented increase of public debt have triggered a strand of literature analyzing the origins of the crisis and discussing the appropriate crisis therapies (see for instance Bernanke 2001; Hoshi and Kashyap 1999; Koo 2003; Caballero, Hoshi and Kashyab 2008).

After a period of financial market exuberance and non-productivity-based wage increases between 2001 and 2007, the European financial and debt crisis took its course in a set of European periphery countries. Despite consolidation efforts and successes in several crisis economies, the IMF growth projections for the euro area remain sluggish. In most crisis countries public debt continues to increase and, by 2016, the European Central Bank continues to ease monetary conditions. Like in Japan an exit from unconventional monetary policy is not in sight.

Fig. 1: Pre- and Post-Peak Real Growth Rates in Japan and Euro Area

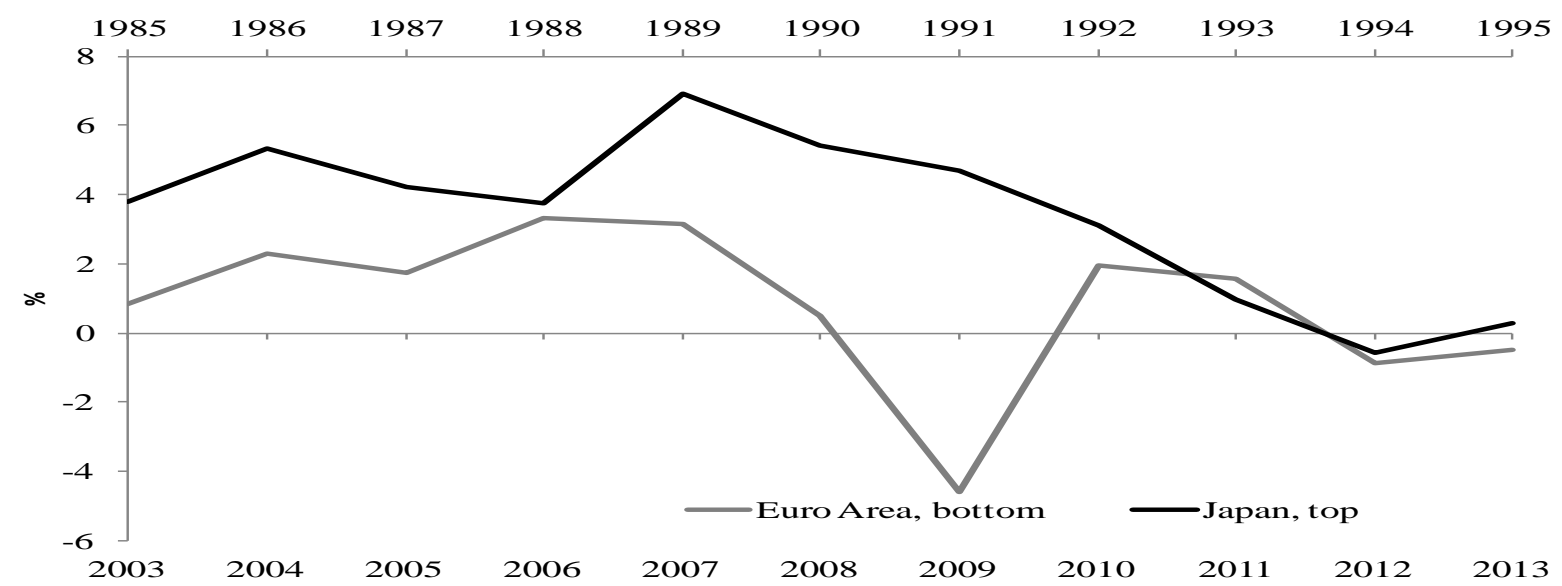

Source: Ameco EU Commission Database; Cabinet Office Japan. The graph displays real GDP growth five years before and after the peak. 
To this end, the post-crisis economic development in the European crisis countries may converge towards Japan. For instance, Krugman (2010) has argued that both significant parts of Europe and Japan face a low inflationary trap, i.e. an economic environment characterized by low interest rates and low inflation. Schnabl (2015) as well as Schaltegger and Weder (2013) see similar macroeconomic response patterns to the bursting of the bubbles, characterized by fiscal and monetary expansion. Vollmer and Bebenroth (2010) argue that the European Central Bank mimics the rescue patterns of the Bank of Japan after 1990, albeit faster and in a more resolved fashion. Mayr (2008) focuses on post-bubble commercial bank lending patterns and finds that in both cases falling asset prices triggered shrinking equity ratios in the respective banking sectors, resulting in tightened credit conditions for enterprises.

Up to the present - to our best knowledge - the role of regional heterogeneity for the evolvement of the crises in Japan and the European Monetary Union has not been compared. Both Japan and the European Monetary Union exhibit a high degree of disparity in regional income levels, what is playing in both cases a significant role for the crisis therapies. The paper aims to shed light on the role of regional divergence for crisis and crisis therapies in Japan and Europe to provide insights in the possible future evolvement of crisis and crisis therapies in Europe. Because the outbreak of the crisis in Japan foreruns Europe for about 15 years, Japan is for this purpose an important case study.

\section{Macroeconomic Shocks and Regional Heterogeneity in Japan and Europe}

Both, Japan and Europe have experienced - at different point of times - exuberant financial market booms, which were followed by severe crisis. A speculation boom in the Japanese stock and real estate markets from 1985 to 1989 found its end with the bursting of the stock market bubble in December 1989. In Europe, starting from the turn of the millennium, on the back of buoyant capital inflows, growth in a group of periphery countries accelerated. The boom phases were accompanied by real estate, stock market and/or (government) 
consumption booms. Starting from 2008 major parts of Europe slipped into deep recessions. In both Europe and Japan, boom and bust in financial markets have taken place in economically heterogeneous areas.

\subsection{Financial Market Shocks as Starting Points of Persistent Crisis}

In Japan, the origins of an unsustainable financial market boom - the so-called bubble economy - can be traced in interest rate cuts by the Bank of Japan in response to painful yen appreciation (Funabashi 1989). When the Japanese yen appreciated triggered by the September 1985 Plaza-Agreement by about 50\%, this led to a deep slump of the exportdependent Japanese economy. The Bank of Japan cut strongly interest rates to stop the appreciation pressure and to facilitate the restructuring process of the export industry (McKinnon and Ohno 1997). The result was an uncontrolled credit expansion and a speculation boom in the Japanese stock and real estate markets, which was ex post dubbed "bubble economy” (Bayoumi and Collyns 2000) (See upper panel of Figure 2). The boom was further accelerated by growing public expenditure following the February 1987 Louvre Accord (Funabashi 1989).

Following the bursting of the Japanese bubble economy in December 1989 the stock and real estate prices strongly declined. The Nikkei 225 lost over $40 \%$ within one year, with stock prices continuing to decline mainly until the start of the Abenomics in early 2013. The Japanese households and - in particular - financial institutions faced painful contractions of their balance sheets. In the early phase of the post-bubble recession Japanese banks and enterprises could partially compensate their losses by participating in the boom phases in the Southeast Asian countries. ${ }^{1}$

\footnotetext{
1 The boom phases in the southeast Asian countries were accelerated by capital inflows (in form of bank-based
} lending) from Japan, where the central bank kept interest rates low to facilitate the economic recovery. 
Fig. 2: Japanese and Euro Area Pre- and Post-Peak Stock and Housing Prices

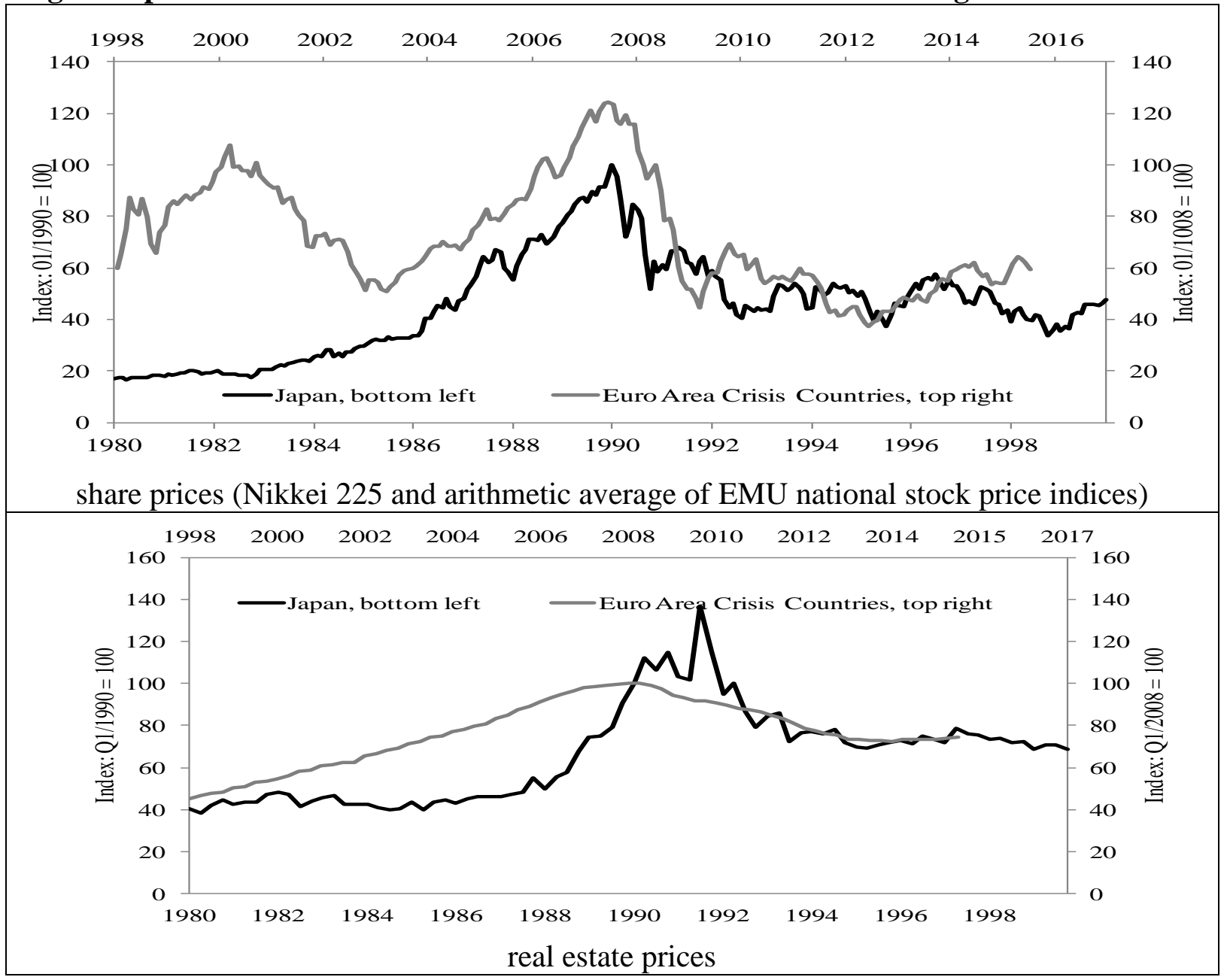

Source: Thomson Reuthers Datasteam, OECD, Oxford Economics. The year 1990 is assumed to be the starting point of the crisis in Japan. The year 2008 is assumed to be the starting point of the crisis in the European (Monetary) Union. Price indices are shown ten years prior and after the peaks. For the euro area arithmetic averages are compiled. EMU crisis countries are Portugal, Italy, Ireland, Greece, Spain.

With the 1997/98 Asian crisis, however, the bad loan problem for Japanese banks was compounded and Japanese exports to Southeast Asia declined. The resulting Japanese financial crisis (1998) became the starting point of a perpetuated recession. A decade after the prick of the bubble overall Japanese house prices had slipped by 30\% (lower panel of Fig. 2). With private financial institutions reducing their exposure to private enterprises a sustained credit crunch set in (Woo 2003). Domestic investment as a share of GDP declined from 32\% in 1990 to $20 \%$ in 2014 . The real growth rate converged towards zero. 
In Europe, with euro introduction in 1999 in eleven EU member states interest rates started to decline in set of former high inflation and thereby high-interest rate countries (namely Portugal, Ireland, Italy and Spain). Greece joined the euro club in the year 2001, experiencing an unprecedented decline in interest rates. Starting from 2000, the European Central Bank cut interest rates in response to the bursting dotcom bubble. Both factors implied asymmetric interest rate dynamics within the euro area for two reasons. First, (real) interest rates in the southern European euro area countries converged towards the traditionally low German benchmark (De Grauwe 2010).

Second, as stressed by Schnabl and Wollmershäuser (2013), the interest cuts by the European central bank were paired with idiosyncratic fiscal policy stances. In Germany a tight public expenditure path was pursued since the year 2003 in the context of the Agenda 2010, which aimed at fiscal consolidation (Burda 2011). This reform process was accompanied by restructuring in the industrial sector. Both factors dampened economic activity in Germany, which encouraged capital outflows to the countries at the periphery of the European (Monetary) Union. There, capital inflows encouraged increasing government spending and wage increases. The outcome was unsustainable boom phases in many euro area periphery countries (and beyond), which were characterized - inter alia - by stock and real estate booms accompanied by wage increases above productivity increases as well as growing private and public consumption (Lane 2012).

The sentiment changed in 2008 following the outbreak of the US subprime crisis. With capital flows into the European periphery countries drying out, the credit-financed booms ended (Belke et al. 2015). With the outbreak of the European debt and financial crisis in the year 2008, share prices in the EMU crisis countries (Greece, Ireland, Italy, Portugal and Spain) declined by about $40 \%$ within a year (upper panel of Figure 2). House prices in European crisis countries dropped by 30\% within a five-year range (lower panel of Figure 2). Banks in 
the EMU-crisis countries started to face severe credit crunches (Arghyrou and Kontonikas 2012). Similarly, to Japan, seven years after the outbreak of the crisis - despite buoyant growth in Germany - a sustained recovery for most crisis countries and the euro area as a whole is not in sight (Figure 1).

\subsection{Regional Con- and Divergence}

Both in Japan and the euro area boom and bust in financial markets occurred on the back of heterogeneous regional income levels. In this context heterogeneity can be defined either in terms of different levels of regional income per capita or in terms of idiosyncratic cyclical movements of aggregate income. The left hand column of Figure 3 shows the regional divergence of GDP per capita for 47 Japanese prefectures from a cross-section and time dimension. For this purpose the 47 Japanese prefectures are subdivided into five quintiles indicating the range of per capita income in the year 2011. Quintile 1 represents the prefectures with the lowest income per capita, quintile 5 represents the prefectures with the highest income per capita in 2011, including the economic centers Tokyo, Osaka and Aichi. ${ }^{2}$

A high degree of heterogeneity is revealed. ${ }^{3}$ By 2011 the lowest 20\% (quintile 1) in Japan had an average income of 3.0 million yen per capita compared with an arithmetic average of 4.5 million yen in the top 20\% (quintile 5) (see lower panel of Figure 3). That corresponds to an income level of approximately $67 \%$ of the lowest quintile as a share of the highest quintile by 2011. During the high-growth period up to the late 1980s income per capita grew faster in the high-income prefectures: The share of per capita income of the lower-income prefectures out of the highest income percentile tended to decline. During the crisis since 1990 per capita income of lower income prefectures relative to the highest income prefectures tended to increase again, in particular since 2008, when the average income of high-income prefectures

\footnotetext{
2 The groupings are shown in Table 2 in the Appendix.

${ }^{3}$ Note that all these numbers refer to GDP per capita after redistribution (see section 3.1)
} 
declined considerably. Regional heterogeneity - as measured by the standard deviations across the five quintiles with respect to their changes over time - confirm that regional heterogeneity increased strongly during the high growth period until the late 1980s and tended to converge since then.

Fig. 3: Regional Income Divergence in Japan and EMU

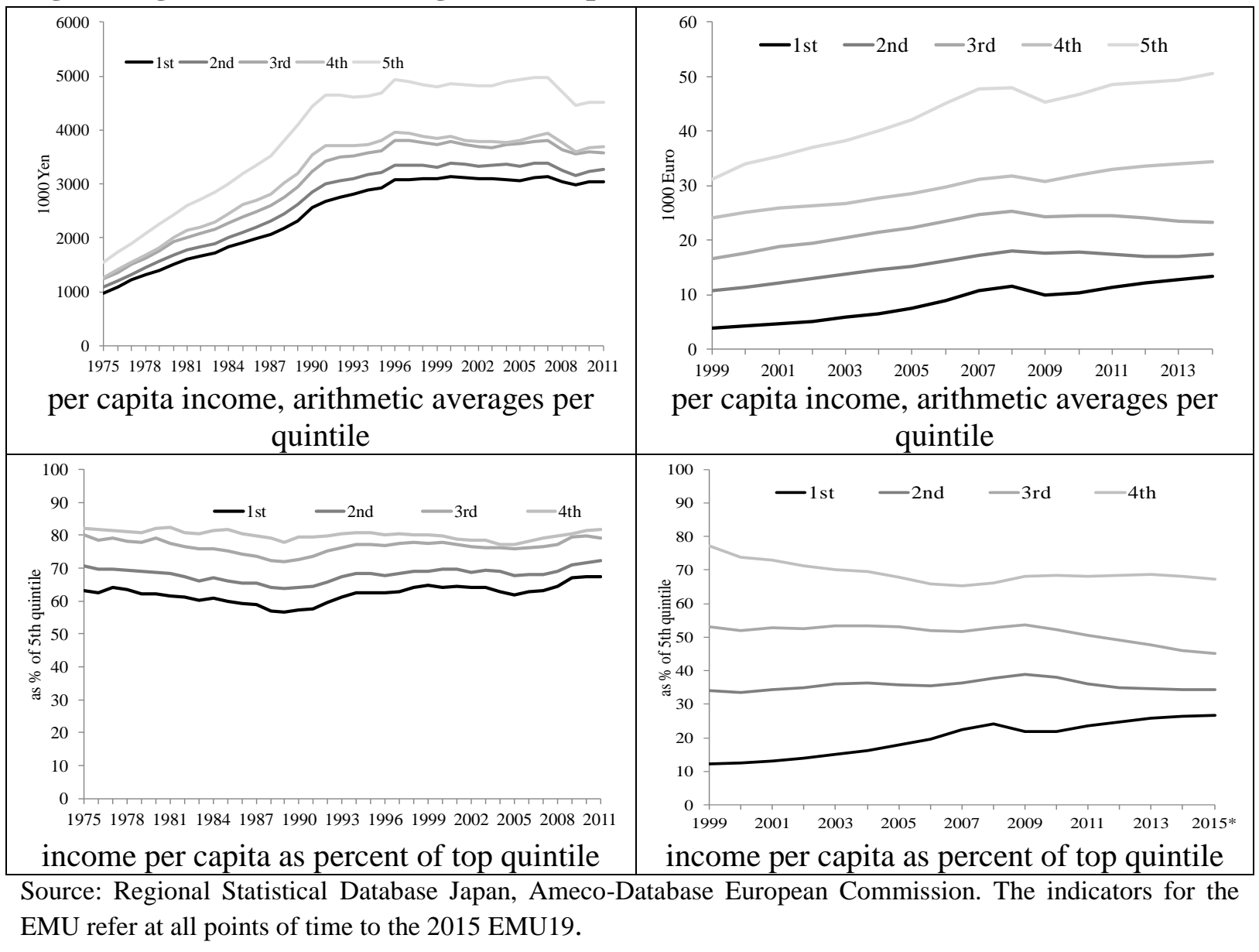

Dispersion of regional per capita income within the euro area is significantly larger than in Japan. In the early years of EMU, with Spain, Portugal and Greece, countries with relatively low per-capita income joined. ${ }^{4}$ With several central and eastern European countries entering the euro area since 2007 income disparities within the euro area further increased. ${ }^{5}$ As shown in the upper right panel of Figure 3 the lowest quintile in terms of GDP per capita (Latvia,

4 This created concerns that the EMU might be subjected to a higher likelihood of asymmetric shocks.

5 Note that the numbers in Figure 3 refer to all now 19 EMU member states during the whole observation period. 
Lithuania, Slovakia, Estonia) only reached 26\% of the highest quintile (Luxemburg, Ireland, Austria, Netherlands) by 2014. The second highest quintile had reached only $67 \%$ of per capita income of the highest quintile (2014) compared to 82\% in Japan (2011).

Also the time dynamics of income disparity are significantly different from Japan. In Europe, the boom phases prior to the crisis were accompanied by a process of economic convergence. The average income of the lower three income quintiles as a share of the highest quintile tended to increase or stay constant between 1999 and 2007 (lower panel of Figure 3). Since the year 2008, the ratios for the second and the third quintiles (which include the crisis countries Spain, Italy, Portugal, Cyprus and Greece) are declining, thereby indicating increasing economic heterogeneity. This is in line with the notion that since the start of the crisis the divergence of income levels has re-emerged again (Christodoulakis 2009). In contrast, the central and eastern European EMU member states as represented by the lowest income quintile are converging again.

Fig. 4: Boxplots of Regional Growth in Japan and EMU

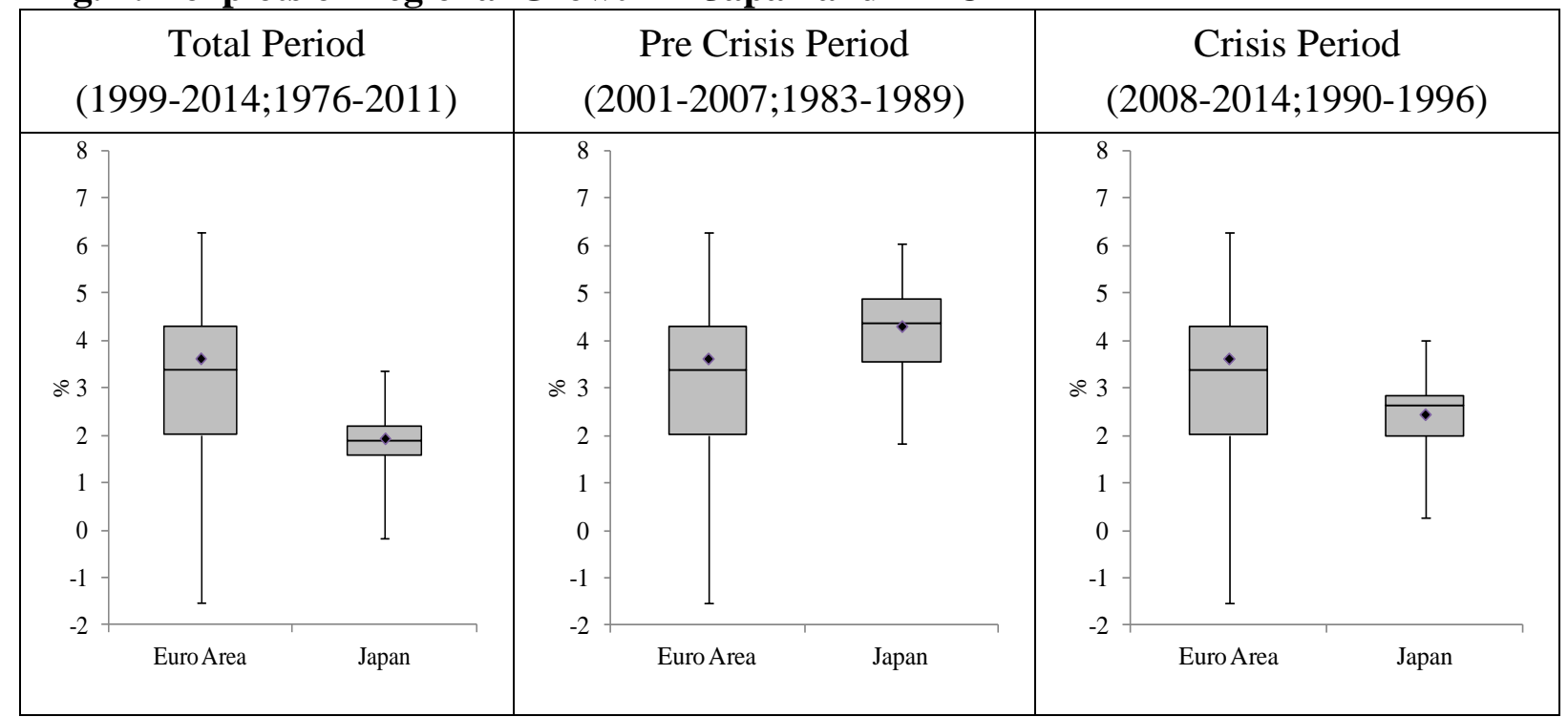

Source: IMF WEO, Statistical Regional Database Japan.

In the case of the EMU the concern that an economically heterogeneous EMU would be subject to asymmetric shocks and idiosyncratic business cycles was confirmed. The box plots 
as shown in Figure 4 reveal a much higher dispersion of regional nominal growth rates in the euro area compared to Japan. ${ }^{6}$ The heights of the boxes reveal the dispersion of period average year-over-year growth rates across sections (prefectures in case of Japan, member states in case of the euro area). For the whole observation period the dispersion of growth rates is much higher for the EMU than for Japanese prefectures, although the observation period is much shorter and the number of cross sections is much smaller. The dispersion of growth rates of Japanese prefectures is extraordinarily low. The finding is the same for preand post-crisis sub-periods, when the EMU member states exhibit more idiosyncratic business cycles than Japan.

\section{Regional and Macroeconomic Policy Response Patterns to Crisis}

The crises following the economic turnaround in Japan and the European Monetary Union triggered economic policy response patterns with both regional and supra-regional dimensions. Whereas Japan has an institutionalized fiscal intra-regional income redistribution mechanism - the so-called local allocation tax (Doi 2010; Ishi 1993) -, such a mechanism does not exist in the European Monetary Union. The instruments of regional economic cohesion in the European Union (European Regional Development Fund, European Cohesion Fund, European Social Fund) have a much smaller scale compared to Japans local allocation tax. Keynesian stimulus packages in response to the crisis were used more in Japan than in the European Monetary Union. As fiscal measures were not able to trigger a sustained recovery, in both Japan and the EMU monetary policies resumed a growing role in supporting economic activity.

\subsection{Fiscal Policies as Regional Stabilization Tools}

Japan has a centralized government budget. Therefore, the fiscal impulses originating from the central government can assumed to be symmetric in the first place. During the Japanese

\footnotetext{
6 We assume for parsimony that inflation rates in Japan and euro area are similar and low.
} 
bubble economy the additional government spending tended to give additional momentum to the speculative upswing of the country as a whole (Funabashi 1989, Schnabl 2015). During the crisis several Keynesian stimulus packages aimed to soften the negative growth shocks ${ }^{7}$ originating in re-emerging crisis (Powell 2002). From 1990 to 2014 several fiscal stimulus packages were set up by the central government to sustain growth (Yoshino and Mizuguchi 2011).

In contrast, in the EMU fiscal policy-making remains decentralized on a national level. In the wake of the crisis, supra-national Keynesian economic stimulus packages could not be implemented, as a common fiscal authority in the EMU does not exist. In addition, in most EMU member states general government debt levels had grown above the Maastricht limit of $60 \%$ of GDP, what constituted an important impediment for anti-cyclical spending (Gabrisch and Staehr 2014). Only in 2014 a pan-EU investment program was launched with a size of 315 billion euros, which was mainly based on a sophisticated leveraging scheme (European Commission 2015). ${ }^{8}$

To ensure homogeneous regional living standards, Japan has developed a comprehensive regional transfer system (Doi 2010). The transfer system from the center to the periphery has two dimensions. ${ }^{9}$ First, there is an explicit fiscal transfer mechanism from the central government to the regions dependent on the relative economic strength of the individual prefecture, the so-called Local Allocation Tax (LAT) (Mochida 2001). The LAT grants are calculated for each prefecture as the difference of the "standard fiscal revenues" (including averaged estimated tax revenues and grants from other distribution mechanisms) and the

\footnotetext{
What is characterized as balance sheet recession (Koo 2005).

The regional distribution of these funds was unknown by spring 2016.

9 The local allocation tax is financed by a fraction of national taxes on income, liquor, tobacco and corporate profits (Shirai 2004). It is therefore collected in all Japanese prefectures. Because the tax revenues can be assumed to be larger in the rich prefectures, there is a second redistribution effect on the income side of the redistribution mechanism, which is not captured here because regional data on the income side are not available.
} 
“standard fiscal needs" (consisting of three factors for each public service branch). ${ }^{10}$ For instance, the prefecture Okinawa (lowest income per capita in 1990) gained on average more than $66 \%$ of total prefectural income via the local allocation tax from 1975 to 2011. In contrast, Tokyo city - having the highest income per capita - never has received any grants from the LAT redistribution mechanism.

Fig. 5: Grants and Tax Revenues by Prefecture Quintiles

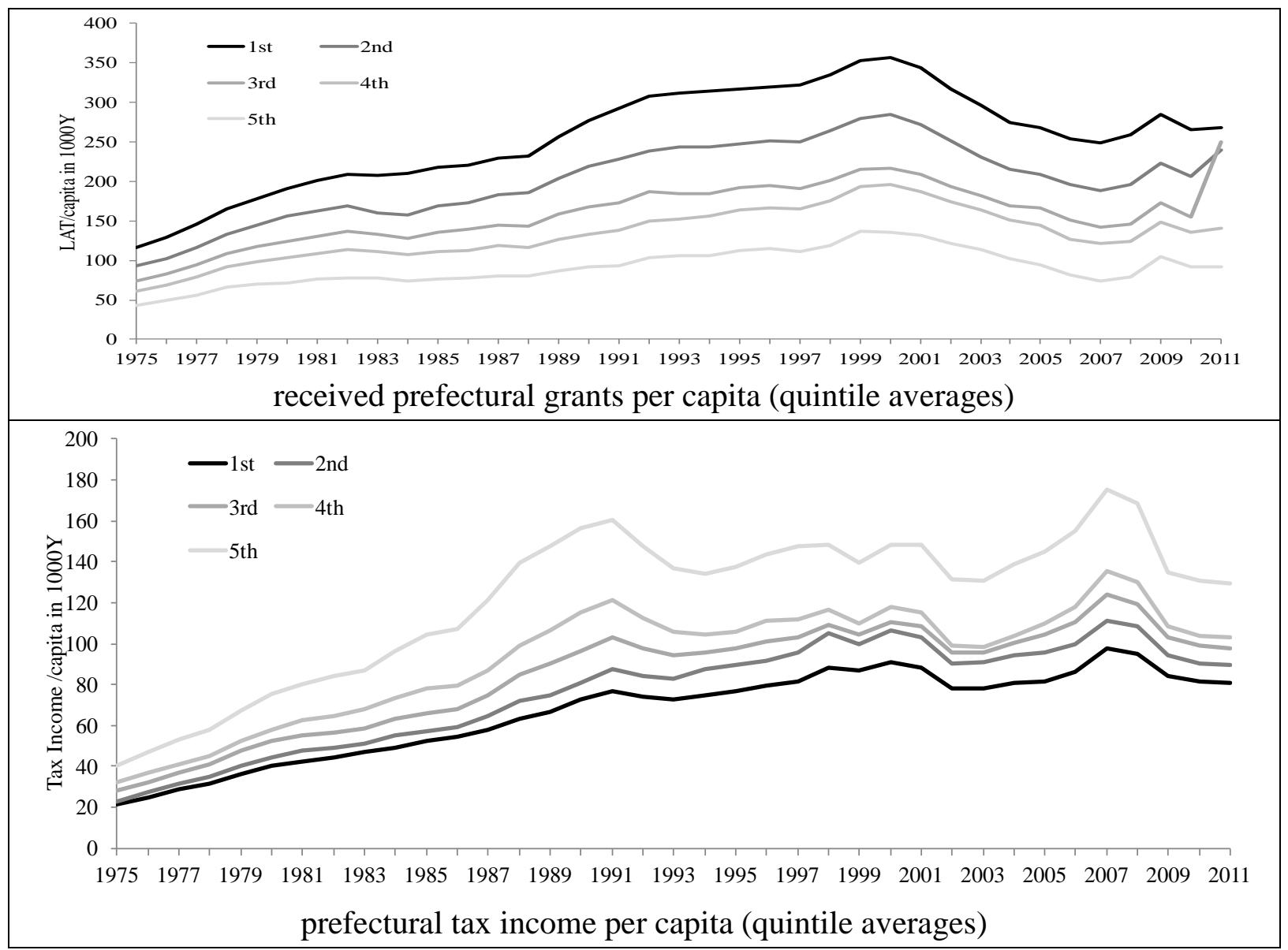

Source: Regional Statistical Database Japan

Second, the social security system, most of which is retirement benefits (83\%) and medical care subsidies, has resumed the role of an indirect regional transfer system, because the periphery is ageing faster than the economic centers (Hashiba et al 1998). Well-educated adolescents tend to move to the more prosperous regions in the economic core of the country,

10 For instance, for the public sector "education" the first of the three factors is a variable measuring the number of pupils and teachers, multiplied by a prefecture-invariant unit cost factor for the respective service branch, and multiplied by a modification factor reflecting prefecture-specific conditions like climate and population density (see Aoki 2008). This shows that the allocation of funds is strongly based on structural factors rather than year-over-year growth rates. This reduces the concern of endogeneity bias in the econometric estimations (see section 4.1.). 
whereas the older generation remains on the countryside. For instance, the share of retirees out of the population in Kochi prefecture is $31 \%$ compared to $22 \%$ in Tokyo city (2012). This implies that a relative higher share of retirement benefits and medical care payments are transferred to Kochi compared to Tokyo.

The total amount of the Local Allocation Tax disbursements increased since the 1970s up to the Japanese financial crisis in 1998. The overall scale was equivalent to $14 \%$ of GDP in the year 1998. Since then, the redistributed funds declined both in absolute terms and in terms of per capita (see upper panel of Figure 5). By 2014 the total volume of the two redistribution mechanisms was 47 trillion yen, which is equivalent to the $10 \%$ of GDP. In many prefectures (prefecture quintiles) the LAT grants per capita received exceeded the per capita local tax revenues (see upper and lower panel of Figure 5). This implies a strong financial dependency of most prefectures on the central transfer mechanism.

Up to the bursting of the bubble, local allocation tax and redistributed funds for social security purposes as a share of total central government revenues remained mainly constant. The local allocation tax fluctuated around a level of $22 \%$ of central government revenues. Social security subsidies fluctuated around $30 \%$ of total revenues. Since then, however, the shares increased dramatically. While tax revenues declined since 1990, the central government aimed to maintain regional and social cohesion by continuing to provide stable funding. Both expenditure categories as shares of tax revenues pointed steeply upwards reaching $28 \%$ (local allocation tax) and 58\% (social security) by 2014 (Figure 6). By 2014 roughly 86\% of total tax revenues were spent for regional redistribution purposes or an expenditure category with a substantial regional redistribution effect. 
Fig. 6: LAT and Social Security Subsidies as Shares of Government Revenues

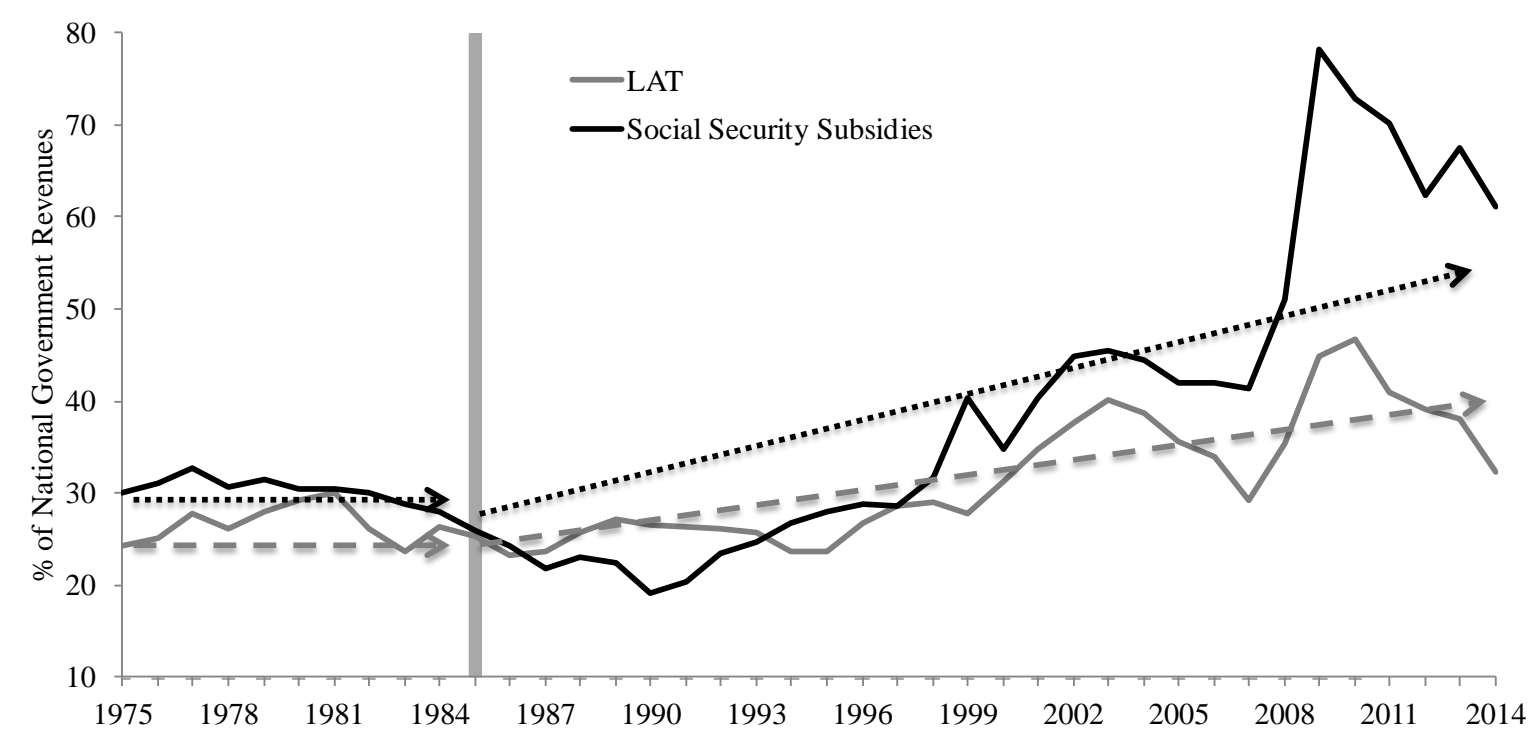

Source: Ministry of Finance Japan.

Because expenditure for the direct and indirect regional redistribution mechanisms increased relative to tax revenues (declined more slowly than tax revenues), ceteris paribus central government debt had to increase, if other expenditure categories were not cut to the same extend. In other words: to maintain regional and social cohesion central government debt in Japan had to rise. Central government debt increased from 368 trillion yen (70\% of GDP) in 1997 to 1029 trillion in 2014 (211\% of GDP), making up by far the biggest share of general government debt of 244\% of GDP (2014) (Figure 7).

Compared to Japan the regional funds of the European Union, which aim to maintain economic, social and territorial cohesion in the European Union, ${ }^{11}$ are small. From 2008 to 2014 the yearly spending of the EU regional funds (European Regional Development Fund, European Social Fund, Cohesion Fund, European Agricultural Fund for Rural Development, etc.) was about 61 billion euros $(\sim 0.4 \% \text { of EU GDP })^{12}$. This compares to 17 trillion yen being redistributed through the Japanese local allocation tax ( 3.5\% of Japanese GDP). The

\footnotetext{
11 "In order to promote its overall harmonious development, the Union shall develop and pursue its actions leading to the strengthening of its economic, social and territorial cohesion.” Art. 174 (1) TFEU

12 The share of EMU member states is 34 billion euros.
} 
transfers under the framework of regional funds are usually tied to specific projects and application procedures. A pan-E(M)U retirement benefit and health care system does not exist.

Fig. 7: Public Spending, Tax Revenues and Central Government Debt in Japan

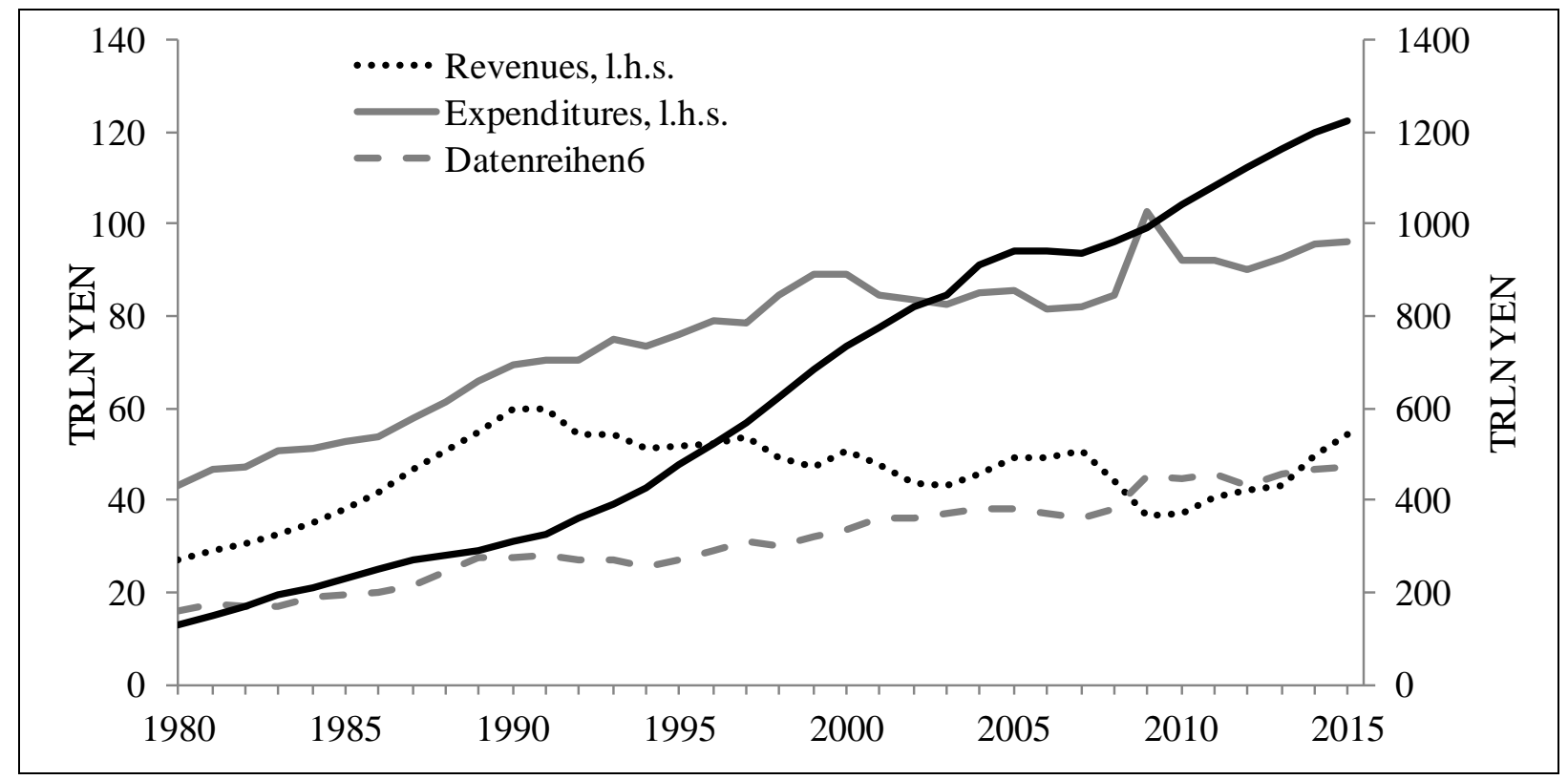

Source: Japan, Ministry of Finance.

\subsection{Monetary Policy as a Regional Stabilization Tool}

In both the euro area and Japan monetary policy gained a growing role in sustaining growth and public finance during the ongoing crisis. On an aggregated level, both the Bank of Japan and the European Central Bank cut interest rates towards zero in the course of the crisis. In the early years after the bubble the Bank of Japan hesitated to cut interest rates to deflate the bubble. As the economy did not recover, starting from 1991 the prime interest rate was finally cut towards $0.5 \%$ by 1995 (see upper panel of Figure 8). The zero-bound was reached in March 1999 in response to the Japanese financial crisis. Up to the present, any attempts to exit from the zero interest rates environment failed (Cargill 2001).

After the short-term interest rate in Japan had reached the zero-bound, the Bank of Japan pioneered unconventional monetary policy measures to depress interest rates at the long end 
of the yield curve. These measures comprised a shift of the monetary policy target to the outstanding current account balances held by financial institutions at the Bank of Japan, the commitment to maintain an expansionary monetary policy stance in future as well as outright purchases of Japanese government bonds and of all kind of other financial assets (Shibamoto and Tachibana 2013).

Fig. 8: Short-Term Money Market Rates and Long-Term Government Bond Yields

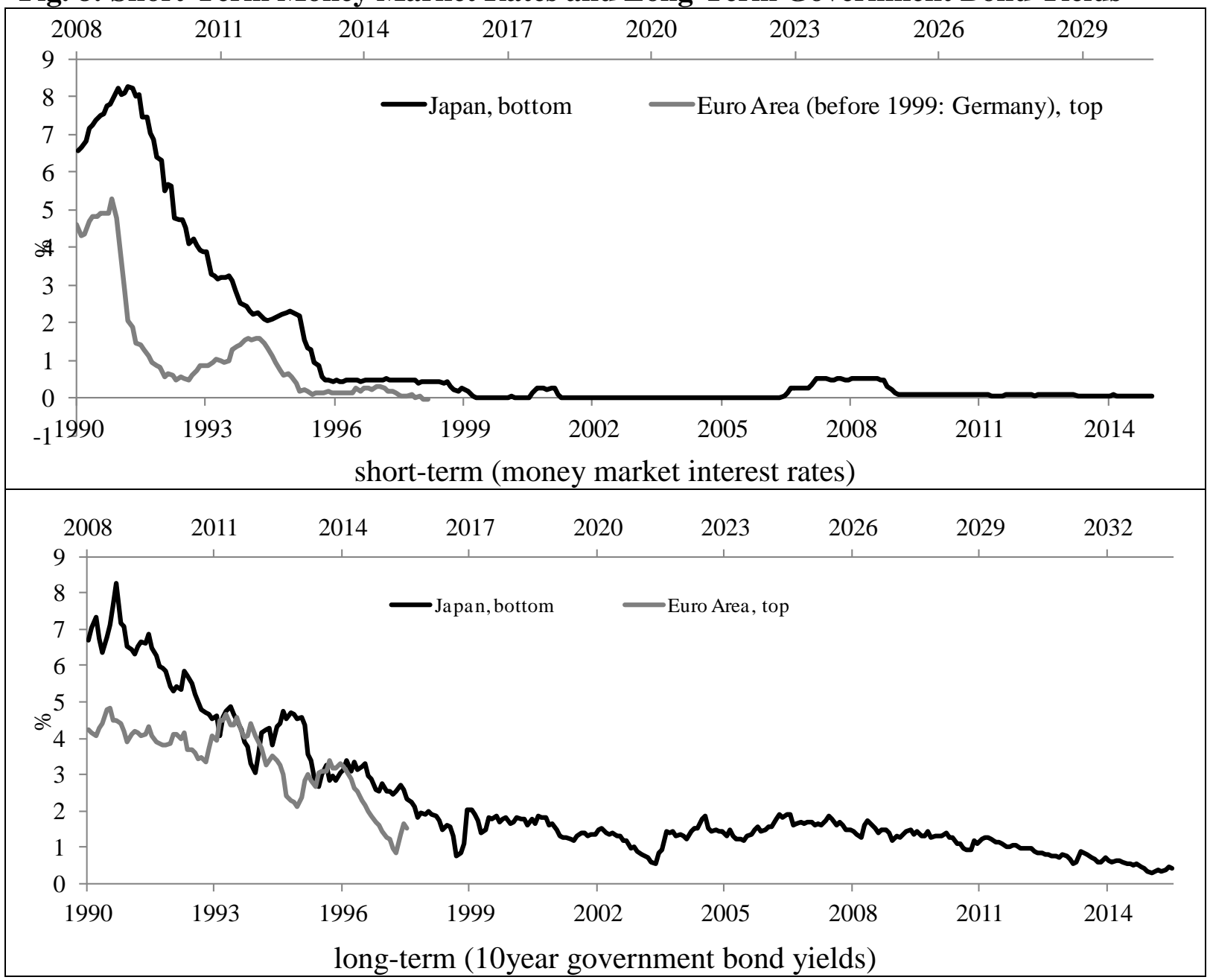

Source: IMF, Japan, Ministry of Finance, OECD. Arithmetic averages of long-term interest rates of euro area member states.

In addition, the unconventional monetary policy provided Japanese commercial banks an incentive to buy government bonds (Kanaya and Woo 2000, Caballero, Hoshi and Kashyab 2008, Schnabl 2015). The outright government bond purchases by the Bank of Japan accelerated with the introduction of the Abenomics starting from the year 2013. These 
measures prevented an increase of long-term interest rates and ensured a further decline of long-term interest rates (e.g. on government bonds). To this end monetary policy can be assumed to have substantially contributed to the sustainability of Japans central government budget and therefore - indirectly - to the sustainability of the regional and social redistribution tools.

The interest cuts of the European Central Bank in response to the crisis started at a lower level in 2008 and reached the zero bound much earlier after the outbreak of the crisis than in Japan (upper panel of Figure 8). Since then, the interest rate on the main refinancing operations has remained at a historically low level. Furthermore, the European Central Bank pioneered a set of unconventional monetary policy measures such as outright purchases of covered corporate bonds, government bonds as well as announcements that any action would be taken to safeguard the euro (Hodson 2013). This helped to prevent a further divergence of euro area government bond yields.

Although the European monetary policy was originally regarded to follow the one-size-fitsall-principle, the unconventional monetary policy measures gained soon a regional dimension. TARGET2 is an interbank payment system for the real-time processing of cross-border transfers throughout the European Union. Pre-crisis the national TARGET2 balances were widely balanced. Shortly after the outbreak of the crisis the TARGET2 payment mechanism attained a redistributive character across different parts of the European Monetary Union, as TARGET2 balances of crisis and non-crisis countries moved into opposite directions (Abad et al. 2013) (see Figure 9).

Via TARGET2 the repatriation of private international credit and deposit flight from the crisis economies was de facto substituted by central bank credit. The balances started to provide an automatic central bank funding for EMU member states suffering capital outflows and current 
account deficits (Sinn and Wollmershäuser 2012). For the commercial banks of crisis countries, the TARGET2 mechanism constituted a liquidity providing system, whereas for the non-crisis it resumed a liquidity absorbing function as deposits increased. In case of exit of TARGET2 deficit countries from the monetary union (while declaring themselves insolvent), the realized losses would be shared among the remaining EMU member states' central bank. Therefore, persistent TARGET2 imbalances can be regarded as an implicit intra-EMU fiscal transfer system in favour of the crisis countries.

Therefore, the pressure on the European Central Bank seems to have increased to forestall a public default of any EMU member states. In May 2010 the European Central Bank launched a government bond purchase program (Security Markets Program / SMP), which was focused on the crisis countries. Up to July 2012, the European Central Bank bought up government bonds of troubled EMU member states worth 218 billion euros ${ }^{13}$. The SMP was accompanied by two covered bond purchase programs (CBPP) to improve refinancing conditions of European corporate banks by buying private assets for a total of 100 billion euro. ${ }^{14}$

In a second step, the European Central Bank announced an unlimited government bond purchase program (Outright Monetary Transaction / OMT) to increase inflation, which ensured the ability of governments of crisis countries to remain able to refinance on capital markets. The OMT program has been argued to have the intention to stabilize the fiscal conditions in the crisis countries. Albeit not having been de facto implemented, interest rates on euro area government bonds are argued to have been affected. For instance, Krishnamurthy, Nagel and Vissing-Jorgensen (2014) show, that the OMT program significantly lowered the interest rates of sovereign bonds of EMU crisis countries.

\footnotetext{
13 Greece (15,5\%), Ireland (6,5\%), Italy (47,2\%), Spain (20,3\%), Portugal (10,4\%).
}

14 A third CBPP has been set up in Oct. 2014. 
Fig. 9: TARGET 2 Balances

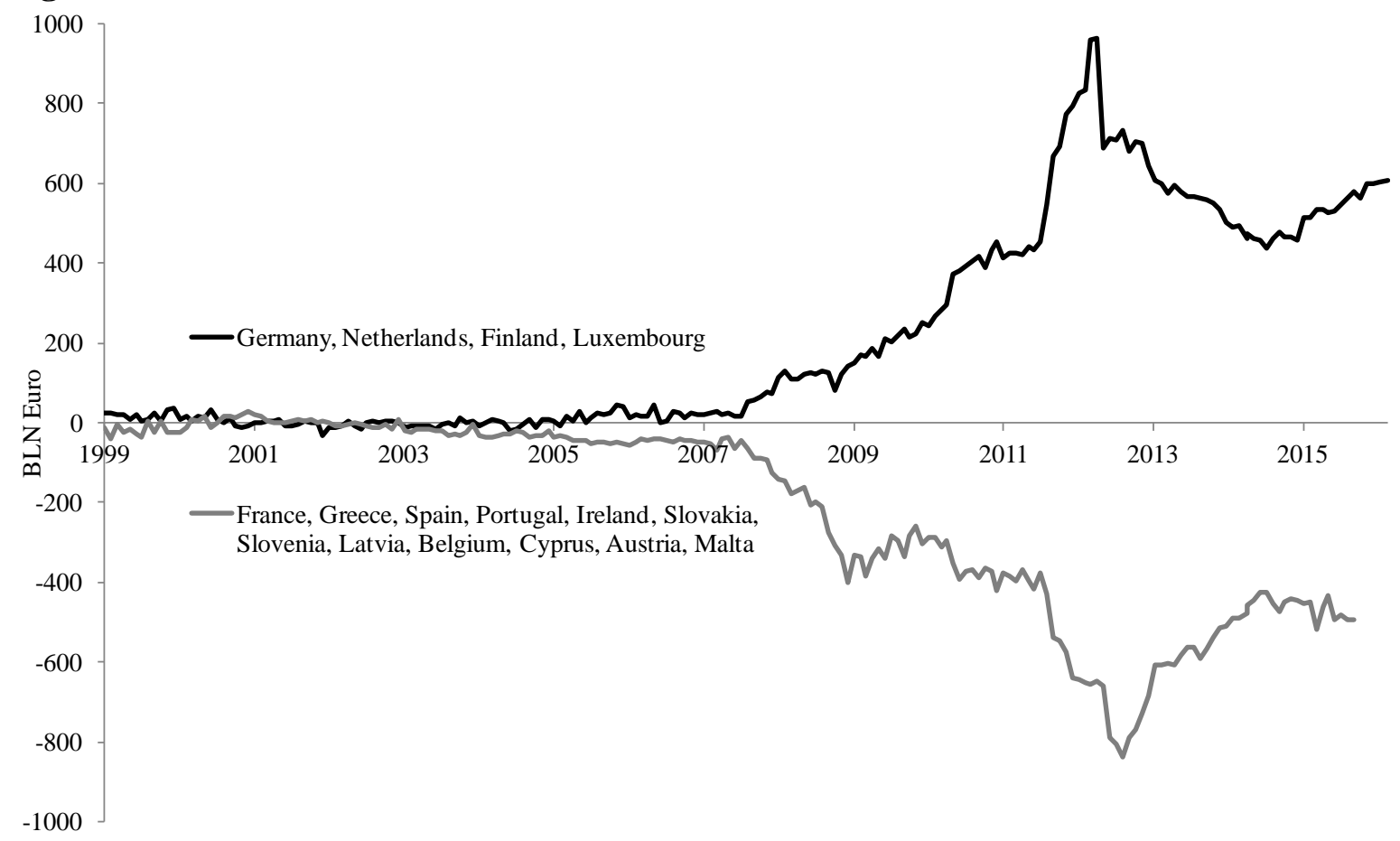

Source: Eurocrisismonitor.com.

Furthermore, the European System of Central Banks allows its national central banks to lend to solvent national commercial banks against collateral in case of emergency. The operations under the so-called Emergency Liquidity Assistance (ELA) are outside the usual monetary policy measures and aim to cure temporary liquidity shortages. ${ }^{15}$ In the case of Greece the emergency liquidity assistance seems to have gained a regional monetary policy character, as it resumed the role of financing the ailing Greek banking sector (rather than providing temporary liquidity assistance). ${ }^{16}$ The risks of these emergency-liquidity-assistance operations are borne in principle by the national central banks (national governments). For the case that the quality of collateral is low, the ELA credit might acquire a regionally redistributive fiscal

15 Note that ELA credits are reflected in TARGET2 balances.

16 The provisions for quality of collateral are less strict than for the standard ECB monetary policy operations. The Bank of Greece got the permission by the ECB governing council to lend a maximum of 90 billion euros. When in summer 2015 this limit was rejected to be increased, the Greek authorities had to close banks and introduce capital controls (Götz et al. 2015). When in August 2015 the euro group passed a 86 billion euro resecue package, this included 25 billion euros for the recapitalization of Greek banks (what can be seen as an indication for the insolvency of the Greek banking sector). 
character when the national central bank is not able to cover the losses from ELA credit provision and the national government turns bankrupt.

In January 2015, the ECB announced an 1100 billion euro bond-purchasing program (Public Sector Purchase Program PSPP) up to autumn 2016. ${ }^{17}$ The program aims to drive up inflation in the euro area by purchases of marketable debt instruments issued by euro area central governments, certain agencies located in the euro area as well as certain international or supranational institutions (including the European Stability Mechanism). ${ }^{18}$ Although, the portfolio of the purchase program is designed to reflect the share of the ECB's capital share (excluding Greece and Cyprus), the program is widely perceived to be motivated by the persistent recession in many crisis countries.

In addition, the European Central Bank allowed national central banks to buy up government bonds on their own account up to a pre-specified limit. In the agreement on net financial assets (ANFA), the national central banks are entitled to pursue national interest in case they are not in conflict with the ECB's target of price stability. Originally, the aim of that secretly decided agreement was to keep national central banks in charge of the management of national foreign reserves and pension schemes. During the crisis this mechanism had been (ab-)used to finance government deficits with the printing press. In December 2015, around 500 billion euros had been created on behalf of this agreement by national central banks, a large fraction of which has been created by monetary expansions of the Central Bank of Ireland, Banca d’Italia and the Banque de France. (see ECB 2016b).

The upshot is that in Japan the conventional and unconventional monetary policy measures can be assumed to have mainly a supra-regional dimension. The regional dimension of macroeconomic policy making is achieved via the fiscal redistribution system. The

\footnotetext{
${ }^{17}$ The ECB announced in March 2016 to expand the program by increasing the monthly purchases from 60 billion euros to 80 billion euros and prolonged the program until at least March 2017 (see ECB 2015 and ECB 2016a).
} 
sustainability of the central government's budget is - given structurally declining tax revenues - ensured by unconventional monetary policy. In the European Monetary Union - due to its specific institutional setting - the scope for additional regional stimulus in the crisis has been limited as national debt levels have mostly surpassed the Maastricht limits. This set the stage for the emergence of a regional monetary policy, which seems to acquire also fiscal dimensions as argued by Sinn (2014) on the OMT program.

\section{Empirical Findings on Transfers and Regional Cohesion in Japan}

Up to the present few empirical evidence has been provided concerning the impact of the local allocation tax on regional cohesion in Japan in the context of the post-bubble crisis. As shown above despite a high degree of regional heterogeneity in Japan, the status quo in regional cohesion seems to have been widely maintained during the crisis despite declining tax revenues. Given that post-crisis the economic dynamics have slowed down and the aging of the Japanese society has continued, regional cohesion seems to have come along with growing public debt and increasing pressure on the central bank to keep monetary conditions loose.

In the empirical part of the paper we aim to test for this hypothesis by identifying the impact of the regional redistribution mechanism on growth of the Japanese prefectures under the side condition of the monetary policy response to crisis. This shall allow us to formulate a scenario concerning the evolvement of regional heterogeneity and monetary policy in Europe given that a comprehensive regional distribution mechanism does not exist and is currently unlikely to be created.

\subsection{Data and Estimation Framework}

The estimation is based on data of annual nominal per capita growth rates of 47 Japanese prefectures from 1975 to 2011 as endogeneous variable. The regional growth data are 
provided by the Japanese Ministry of Internal Affairs and Communications via the Regional Statistical Database (for a data survey see Table 3 in the appendix). The data are only available at yearly frequency. The explanatory variables are the grants of the local allocation tax and national disbursements per capita ${ }^{19}$ from 1975 to 2011 (as provided by the Japanese Cabinet's Office regional statistics database) in first log differences (dlnLAT).

Note that the LAT funds provide only a partial picture of the redistribution effects for two reasons. First, it does not include the financing side. It can be assumed that the underlying tax collection takes place over-proportionally in the wealthy regions (see footnote 9). Second, the redistribution function of the social security system is not included (because respective data are not available). The results can therefore be assumed to underestimate the role of the redistribution mechanisms for regional growth in Japan.

Because monetary policy has gained a growing role for macroeconomic stabilization in Japan (see section 3.2) we include different proxies for the monetary policy stance: High powered money in first log differences $(d \ln M 0)$ as a proxy for both monetary impulses via interest rate cuts (up to 1999) and via unconventional monetary policy measures (since 1999). ${ }^{20}$ As an alternative measure for the monetary policy stance money M1 in first log differences $(d \ln M 1)$ is used. It includes in addition to M0 demand deposits (current deposits, ordinary deposits, saving deposits, deposits at notice, special deposits, and deposits for tax payments) minus checks and bills held by the surveyed financial institutions.

The descriptive statistics are provided in Table 4 in the appendix. Income and LAT-provisions are included in nominal terms. As prefectural inflation rates are not available, normalizing all prefectural growth rates and LAT provision by the national price level would not change the

19 In opposite to the „regular“Local Allocation Tax grants, which are supposed to compensate prefectures to assure the deployment of "basic needs" in every Japanese region, National Disbursements are meant to compensate for special events such as natural catastrophes etc. However, National Disbursements are widely a regular redistribution mechanism (see Regional Statistical Database Item Definition; RD1).

20 Short-term interest rates are a deficient proxy for changes in the monetary policy stance since 1999 because they remain widely unchanged at the zero bound (see Figure 8). 
results. The impact of the local allocation tax on growth in context of the crisis and regional heterogeneity is captured with the help of dummy variables. A post90-dummy is introduced to isolate the crisis period (1990-2011). It takes the value of unity for the years 1990 to 2011 and zero otherwise. The dummy Q5 is compiled for relatively rich prefectures (see Table 2 in the appendix). It takes the value of 1 for the seven prefectures in the highest quintile. ${ }^{21}$ We test each variable for unit roots using the Im-Pesaran-Shin test. For every panel the hypothesis that the series contains a unit root is rejected at the $1 \%$ level (see Table 5 in the appendix).

To identify the impact of changes in regional redistribution mechanisms on the regional growth rates before and after the bursting of the bubble in Dec. 1989 we use a linear fixed effects panel model. The local allocation tax provisions depend on the level of regional fiscal needs, i.e. structural factors, which are independent from year-over-year growth rates. We scrutinize to what extend the role of the local allocation tax has changed for regional growth in Japan in the context of a high degree of regional heterogeneity contingent on the monetary policy stance. For this purpose we specify the following model:

$d \ln G D P_{i t}=\beta_{0}+\beta_{1} d \ln L A T_{i t}+\beta_{2} d \ln L A T_{i t} * p o s t 90_{i}+\beta_{3} d \ln L A T_{i t} * p_{0 o s t 90} * Q 5+$ $\beta_{4} d \ln L A T_{i t} * Q 5+\beta_{5}$ post90+ $f_{i}+\sum_{j=6}^{8} \beta_{j}$ Control $_{j}+\varepsilon_{i t}$

The term $d \ln G D P_{i t}$ is the dependent variable, i.e. the nominal per capita growth rate of prefecture $i$ in the year $t$. The term $d \ln L A T_{i t}$ represents the growth rates of local allocation tax grants and national disbursements per capita in the respective year $t$ for prefecture $i$. The coefficient $\beta_{1}$ is equivalent to the impact of the grants from local allocation tax on the regional growth rates before 1990 in low-income regions. The coefficient $\beta_{2}$ captures the additional effect for low-income regions (quintile 1 to 4 ) since 1990 . The coefficient $\beta_{3}$ indicates the additional growth impulse of growth in LAT grants for the richest quintile of

21 An alternative dummy (rich) is compiled for all prefectures having an income per capita higher than the median prefecture in 1990 (i.e. the year, when the crisis started). The results remain qualitatively unchanged. 
prefectures since 1990, while $\beta_{4}$ captures the same effect before 1990. The term $\beta_{5}$ distinguishes growth paths before and after the breakout of the Japanese crisis. The coefficients $\beta_{j}$ capture the effect of the controls variables on regional growth in Japan. Even though it is generally recommended to implement the interaction terms also as single explanatory variable, we exclude the dummy Q5 due to collinearity with the fixed effects $\left(f_{i}\right)^{\prime}$

\subsection{Estimation Results}

The estimation results are presented in Table 1. The baseline specification (1) provides evidence that before 1990 distributing more grants via the local allocation tax and national disbursements to low-income prefectures positively contributed to the regions' growth. Before 1990 a 1\% increase in local allocation tax grants increased regional GDP per capita growth in low-income prefectures by 0.217 percentage points $\left(\beta_{1}\right)$. This effect is stronger in the period since $1990\left(\beta_{2}\right)$, what implies an even higher positive growth effect of LAT grants for low-income prefectures for the post crisis period $\left(\beta_{1}+\beta_{2}\right)$ :

Table 1: Estimation Results

\begin{tabular}{l|cccc}
\hline & $(1)$ & $\begin{array}{c}(2) \\
\text { control M0 } \\
\text { GDP }\end{array}$ & $\begin{array}{c}(3) \\
\text { Control M1 } \\
\text { GDP }\end{array}$ & $\begin{array}{c}(4) \\
\text { Control M0 } \\
\text { GDP \& Lag }\end{array}$ \\
\hline$\beta_{1}$ : LAT & GDP & $0.178^{*}$ & $0.188^{* *}$ & $0.182^{*}$ \\
& $0.217^{* *}$ & $(2.46)$ & $(2.60)$ & $(2.51)$ \\
$\beta_{2}$ : LAT \#post90 & $(3.04)$ & $0.537^{* * *}$ & $0.528^{* * *}$ & $0.530^{* * *}$ \\
& $0.497^{* * *}$ & $(7.31)$ & $(7.24)$ & $(7.22)$ \\
$\beta_{3}$ :LAT\#post90\#Q5 & $(6.90)$ & $-0.730^{* * *}$ & $-0.721^{* * *}$ & $-0.730^{* * *}$ \\
$\beta_{4}$ : LAT\#Q5 & $(-4.58)$ & $(-4.61)$ & $(-4.55)$ & $(-4.62)$ \\
$\beta_{5}$ : post90 & -0.057 & -0.0515 & -0.0556 & -0.0499 \\
$\beta_{6}$ : M0 & $(-0.39)$ & $(-0.36)$ & $(-0.38)$ & $(-0.35)$ \\
& $-5.163^{* * *}$ & $-4.345^{* * *}$ & $-5.286^{* * *}$ & $-4.460^{* * *}$ \\
& $(-7.57)$ & $(-5.83)$ & $(-7.74)$ & $(-5.97)$ \\
& & $0.260^{* *}$ & & $0.255^{* *}$
\end{tabular}




\begin{tabular}{|c|c|c|c|c|}
\hline$\beta_{7}: \mathrm{M} 1$ & & & $0.144^{*}$ & \\
\hline & & & $(2.54)$ & \\
\hline$\beta_{8}:$ GDPt-1 & & & & $-0.0300^{*}$ \\
\hline & & & & $(-2.28)$ \\
\hline$\beta_{0}:$ Cons & $5.464^{* * *}$ & $3.467^{* * *}$ & $4.655^{* * *}$ & $3.673^{* * *}$ \\
\hline & $(9.40)$ & (3.69) & (7.03) & (3.89) \\
\hline$\beta_{1}+\beta_{2}$ & $0.714^{* * *}$ & $0.715^{* * *}$ & $0.716^{* * *}$ & $0.712^{* * *}$ \\
\hline$\beta_{1}+\beta_{4}$ & $0.160^{* * *}$ & $0.127^{* *}$ & $0.132^{* * *}$ & $0.132^{* *}$ \\
\hline$\beta_{1}+\beta_{2}+\beta_{3}+\beta_{4}$ & $-0.069^{* * *}$ & $-0.067^{* * *}$ & $-0.061^{* * *}$ & $-0.068^{* * *}$ \\
\hline$\beta_{3}+\beta_{4}$ & $-0.784^{* * *}$ & $-0.782^{* * *}$ & $-0.777^{* * *}$ & $-0.780^{* * *}$ \\
\hline$\left(\beta_{1+} \beta_{2}\right) / \beta_{1}$ & 3.290 & 4.017 & 3.809 & 3.912 \\
\hline$N$ & 1692 & 1692 & 1692 & 1691 \\
\hline
\end{tabular}

Note: The dependent variable is dlnGDP and all regressions include a prefectural fixed effect. dlnLAT, dlnM0, dlnM1 and dlnGDPt- 1 are growth rates. Robust standard errors are reported in parentheses. The significance of coefficients is reported at the $10 \%, 5 \%$, and $1 \%$ level, indicated by $*, * *, * * *$, respectively.

A $1 \%$ increase in the local allocation tax, increased prefectural income by 0.714 percentage points in low income prefectures. The positive income effects of the local allocation tax for the low-income prefectures are statistically significant at the common levels for the pre-crisis and crisis period.

For the richest prefectures the additional growth effect of LAT grants is lower than for the low-income prefectures. This is the case for both the crisis period since $1990\left(\beta_{3}:-0.727\right)$ and before $1990\left(\beta_{4}:-0.057\right)$, albeit for the pre-1990 period this effect is not statistically significant and economically small (-0.057 percentage points). Rich prefectures on average before 1990 gained only 0.16 percentage points in GDP growth for a $1 \%$ increase in tax grants $\left(\beta_{1}+\beta_{4}\right)$. Since 1990 , the grants do not have any positive impact on regional GDP of the richest prefectures any more. The effect $\left(\beta_{1}+\beta_{2}+\beta_{3}+\beta_{4}\right)$ is moreover slightly negative (-0.069) and statistically significant. 
This implies that since the start of the crisis in 1990 the role of fiscal redistribution on regional growth has changed significantly. Poorer regions growth has been much more affected by regional redistribution. Compared to the pre-crisis period, the relevance of LAT grants for growth in poorer prefectures has risen by 0.497 percentage points $\left(\beta_{2}\right)$. The dependency of redistribution via the transfer system as expressed by $\left(\beta_{1}+\beta_{2}\right) / \beta_{1}$ has more than tripled (3.290). The difference in dependency on redistribution is substantially larger for low-income prefectures compared to high-income prefectures. $\left(\beta_{3}+\beta_{4}: 0.784\right)$.

The specifications (2) and (3) control additionally for the effects of monetary policy on regional growth in Japan. Note that the inclusion of the proxies for the Bank of Japan monetary policy stance only controls for the direct effects of monetary policy on growth. It does not capture the indirect effects linked to the fact, that monetary expansion has increasingly become an important precondition for LAT provision. For the both proxies (MO and M1) the effect on regional growth in Japan is as expected positive and statistically significant $\left(\beta_{6}\right.$ and $\left.\beta_{7}\right)$. The overall growth effects of LAT provision get smaller. For example, the growth effects of LAT grants in low-income regions drop from 0.217 percentage points (pre-1990) to 0.178 in specification (2).

However, the main result that the dependency of growth on LAT provision after the burst of the bubble in low-income prefectures remains unchanged. The difference of growth response to LAT grant changes between rich and poor regions stays roughly the same at 0.782 percentage points $\left(\beta_{3}+\beta_{4}\right)$ and 0.777 respectively. Given that less and more prosperous regions have grown (or stagnated) homogeneously (see Fig. 4), our results indicate that it is only due to the regional redistribution mechanisms, the single most important of which is the LAT, that income levels of Japanese prefectures did not diverge significantly.

Specification (4) controls for monetary policy measures as well as lagged growth rates. By adding the lagged annual growth rate we assure that the effect of LAT grants and income 
growth is not due to a growth trend. Since the distribution of LAT grants is mainly tied to structural factors rather than growth rates, and since the growth rates of Japanese prefectures happen to be fairly uncorrelated $\left(\beta_{8}\right)$, the concern with respect to this bias is low. The results remain widely unchanged.

On average, low income regions in real terms grew after 1990 by $0.62 \%$ per a year, the richest quintile in the same period on average by $0.61 \%$. To simulate the divergence of regional income levels in Japan if the local allocation tax would not have existed, we subtract the contribution of LAT grants from the average growth rates and compile alternative growth paths. In this simulation, without regional redistribution the per capita income of low-income regions on average would have shrunk by $0.09 \%$ each year $(0.62-0.714)$. The top quintile regions would have grown on average by $0.67 \%$ per capita $(0.61+0.069)$. The resulting stylized growth paths are depicted in Fig 10.

We have modified the baseline estimation equation to check the robustness of the results. We controlled for the sensitivity of the selection of prosperous and less prosperous prefectures by estimating the equation with a "rich" dummy instead the Q5 dummy. The "rich" dummy is 1 for all prefectures, where GDP per capita in 1990 was higher or equal to the median prefecture. We also varied our estimation by changing the crisis dummy from post 1990 to post 1998 as the Asian crisis and the Japanese financial crisis dampened Japanese government tax revenue from then on substantially. We also modified our estimation method by using a robust cluster estimator (vce robust) to control for various forms of heteroscedasticity. The results remained qualitatively unchanged. All in all, the estimation results confirm that Japanese periphery prefectures got more dependent on transfers from the central government after the bursting of the bubble.

Fig 10: Simulated Income Paths in Japanese Prefectures without LAT Provision 


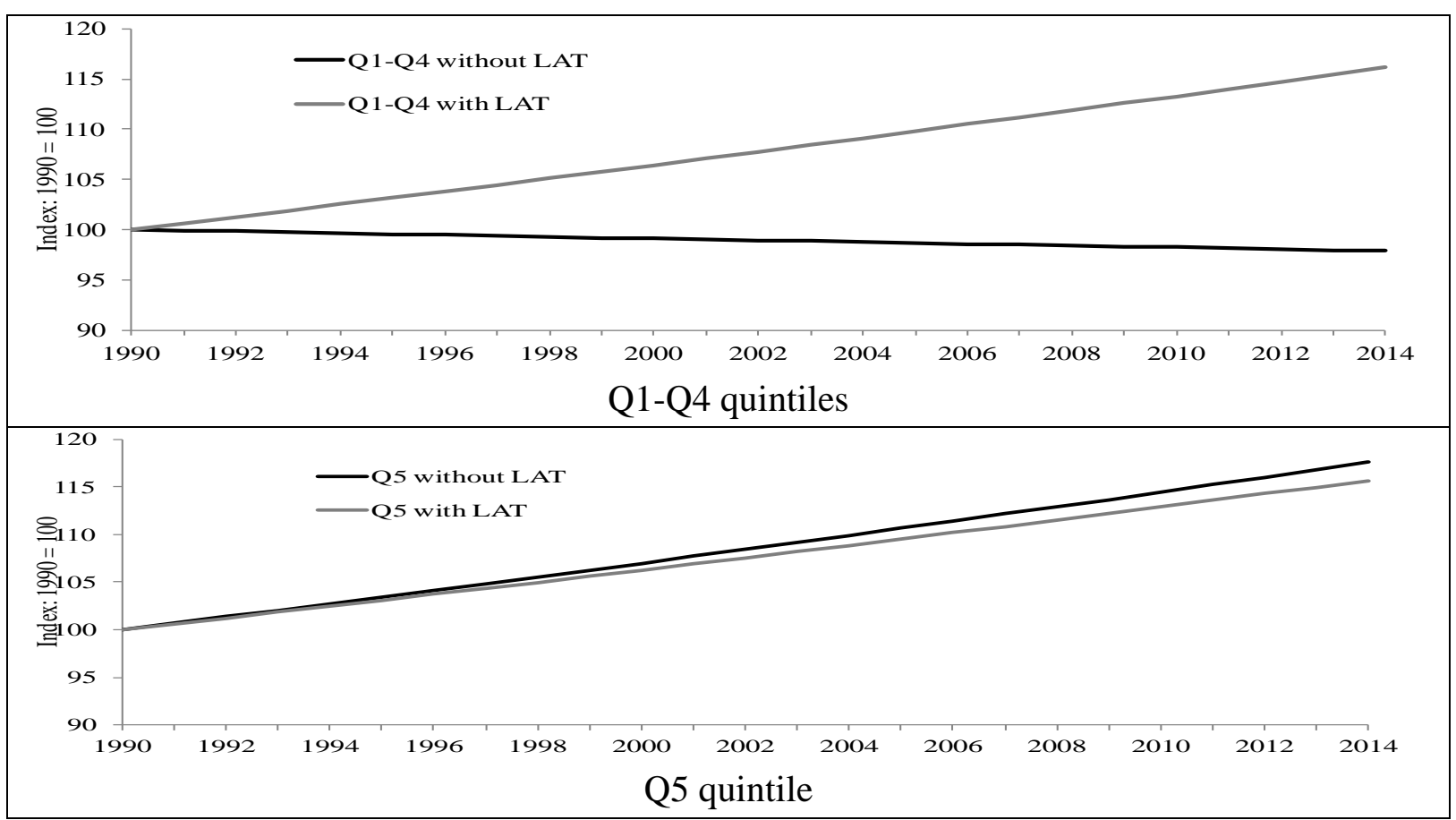

Source: Own calculation.

\section{Conclusion}

Both Japan and the euro area are economic areas with heterogeneous regional income levels. Both have experienced at different points of time unsustainable exuberance in real estate and stock markets. The bursting of the bubbles were the starting points of lasting recessions in both Japan and parts of the euro area. We have aimed to understand the macroeconomic response patterns to the crisis in the context of regional heterogeneity. We have argued for Japan that given a common monetary policy and the absence of limits to general government debt, fiscal policy has taken the role of safeguarding regional (and social) cohesion in aging Japan.

The econometric exercise has provided evidence that both the regional distribution mechanism as well as monetary policy have helped to sustain growth in Japanese peripheral prefectures (albeit at low levels). This finding only partially captures the fact that the unprecedented monetary expansion can be seen as a prerequisite for the regional 
redistribution, because without unconventional monetary policy measures the central government debt can be assumed to have become unsustainable. The upshot is that since the start of the crisis the regional (and social) cohesion in Japan strongly hinges on regional redistribution, public debt and thereby the extension of unconventional monetary policy measures.

In contrast, in Europe with start of the crisis, the regional heterogeneity within the euro area has increased. That can be due to the fact that in contrast to Japan a systematic regional redistribution mechanism does not exist and the Maastricht provisions on public debt put strong restrictions on national fiscal stabilization measures in the crisis. Therefore, fragments of a regional monetary policy seem to have emerged, which seem to have acquired also aspects of a intra-euro area redistribution mechanism. Given the Japanese experience, this is straightforward from the point of view that a regional transfer mechanism in Europe does not exist and an increase of public debt levels is impeded by the institutional limits to government debt. The use of euro area monetary policy as a kind of regional fiscal policy may interfere, however, with the obstacle of the prohibition of monetary financing of public expenditure (Art. 123 TFEU). 


\section{References}

Abad, Jose, Löffler, Axel, Schnabl, Gunther, Zemanek, Holger, Fiscal Divergence, Current Account and TARGET2 Imbalances in the EMU, Intereconomics: Review of European Economic Policy, Springer 48, 1, 51-58.

Aoki, Ichiro, 2008, Decentralization and Intergovernmental Finance in Japan, PRI Discussion Paper Series, 8A, 4.

Arghyrou, Michael G. and Kontonikas, Alexandros, 2012, The EMU Sovereign-Debt Crisis: Fundamentals, Expectations and Contagion, Journal of International Financial Markets, Institutions and Money, 22, 4, 658-677.

Bayoumi, Tamim and and Collyns, Charles, 2000, Post-Bubble Blues: How Japan Responded to Asset Price Collaps, International Monetary Fund.

Belke, Ansgar, Haskamp. Ulrich, Schnabl, Gunther and Zemanek, Holger 2015: Beyond Balassa and Samuelson: Real Convergence, Capital Flows, and Competitiveness in Greece. Forthcoming as CESifo Working Paper.

Bernanke, Ben, 1998, It's baaack: Japan's Slump and the Return of the Liquidity Trap, Brooking Papers on Economic Activity, 2.

Burda, Michael C., Hunt, Jenifer, 2011, What Explains the German Labor Market Miracle in the Great Recession?, National Bureau of Economoic Research Working Paper, 17187.

Cargill, Thomas F., 2001, Monetary Policy, Deflation, and Economic History, Lessons for the Bank of Japan, Monetary and Economic Studies - Special Edition, 2001.

Caballero, Ricardo J., Hoshi, Takeo and Kashyab Anil K., 2008, Zombie Lending and Depressed Restructuring in Japan, American Economic Review, 98, 5, 1943-1977.

Christodoulakis, Nikos, 2009, Ten Years of EMU: Convergence, Divergence and New Policy Priorities, Hellenic Observatory Papers on Greece and Southeast Europe, 22.

De Grauwe, Paul, 2010, Crisis in the Eurozone and How to Deal With it, CEPS Policy Brief, 204.

Doi, Takero, 2010, Poverty Traps with Local Allocation Tax Grants in Japan, Keio/Kyoto Global Coe Discussion Paper Series, DP2010-002.

ECB (2015): https://www.ecb.europa.eu/mopo/implement/omt/html/index.en.html, as of September 2015.

ECB (2016a): https://www.ecb.europa.eu/mopo/implement/omt/html/index.en.html as of April 2016.

ECB (2016b): https://www.ecb.europa.eu/explainers/tell-me-more/html/anfa_qa.de.html, as of April 2016.

European Commission 2015: http://www.europarl.europa.eu/news/en/newsroom/content/20150622IPR69218/html/Juncker-Plan-Parlament-billigt-Investitionsplanzur-Konjunkturbelebung; as of August $22^{\text {nd }} 2015$. 
Götz, Martin R., Haselmann, Rainer, Krahnen, Jan P., Steffen, Sascha, 2015, Did emergency liquidity assistance (ELA) oft he ECB delay the bankruptcy of Greek banks? Sustainable Architecture for Finance in Europe Policy Letter, 46.

Ishi, Hiromitsu, 2001, The Japanese Tax System, Oxford University Press, New York.

Funabashi, Yoichi, 1989, Managing the dollar: From the Plaza to the Louvre, DC, Institute for International Economics.

Gabrisch, Hubert, and Staehr, Karten, 2014, The Euro Plus Pact: Cost Competitiveness and External Capital Flows in the EU Countries, ECB Working Paper, 1650.

Hashiba, H., Kameda, K. Sugimura, T., Takasaki, K., 1998, Analysis of landuse change in periphery of Tokyo during last twenty years using the same seasonal landsat data, Advances in Space Research, 22, 5, 681-684.

Hayashi, Fumio, Prescott, Edward C., 2002, The 1990s in Japan: A Lost Decade, Review of Economic Dynamics, 5, 206-235.

Hodson, Dermot, 2013, The Eurozone in 2012, Whatever it Takes to Preserve the Euro?, Journal of Common Market Studies, 51, 183-200.

Hoshi and Kashyap, 1999, The Japanese Banking Crisis: Where did it Come From and How Will it End?, NBER working paper, 7250.

Kanaya, Akihiro and Woo, David, 2000, The Japanese Banking Crisis of the 1990s: Sources and Lessons, IMF Working Paper, 00/7.

Koo, Richard, 2003, Balance Sheet Recession: Japan's Struggle with Uncharted Economics and its Global Implications, Wiley and Sons.

Krishnamurthy, Arvind, Nagel, Stefan, Vissing-Jorgensen, Annette, 2014, ECB policies involving government bond purchases: Impacts and channels, Mimeo.

Krugman: http://krugman.blogs.nytimes.com/2010/03/17/how-much-of-the-world-is-in-aliquidity-trap/?_r=0, 2010, as of June $23^{\text {rd }} 2015$.

Lane, Philip, 2015, The European Souvereign Debt Crisis, Journal of Economic Perspectives, 26, 3, 49-68.

Mayr, Johannes, 2008, The Financial Crisis in Japan - Are there Similarities to the Current Situation, CESifo Forum, Ifo Institute for Economic Research , 9, 4, 64-68.

McKinnon, Ronald, and Ohno, Kenichi, Dollar and Yen: Resolving the Economic Conflict between the United States and Japan, MIT Press Books, Cambridge, Massachusetts 1997.

Mochida, Nobuki, 2001, Taxes and Transfers in Japan’s Local Public Finances, World Bank Institute, 37171.

Powell, Benjamin, 2002, Explaining Japan's recession, The Quarterly Journal of Austrian Economics, 5, 22, 35-50.

Schaltegger, Christoph, Weder, Martin, 2013, Will Europe Face a Lost Decade? A Comparison With Japan's Economics Crisis, Center for Research in Economics, Management and the Arts Working Paper Series, 2013-03. 
Schnabl, Gunther, 2015, Monetary Policy and Structural Decline: Lessons from Japan for the European Crisis. Asian Economic Papers, 14, 1, 124-150.

Schnabl, Gunther, Wollmershäuser, Timo, 2013, Fiscal Divergence and Current Account Imbalances in Europe, CESifo Working Paper Series, 1408.

Shibamoto, Masahiko and Tachibana, Minoru 2013: The Effect of Unconventional Monetary Policy on the Macro Economy: Evidence from Japan's Quantitative Easing Policy Period. Kobe University RIEB Discussion Paper Series 12.

Shirai, Sayuri, 2004, The Role of Local Allocation Tax and Reform Agenda in Japan Implication to Developing Countries. Policy and Governance Working Paper Series, 32.

Sinn, Hanns-Werner 2014: Stellungnahme des ifo Instituts und von Prof. Hans-Werner Sinn zur heutigen Erklärung des Bundesverfassungsgerichts zum OMT-Programm der EZB, München 07.02.2014.

Sinn, Hans-Werner, Wollmershäuser, Timo, 2012, Target loans, current account balances and capital flows: the ECB's rescue facility, International Tax and Public Finance, 19,4 468508.

Vollmer, Uwe, Bebenroth, Ralf, 2012, The Financial Crisis in Japan: Causes and Policy Reactions by the Bank of Japan, The European Journal of Comparative Economics, 9, 155-181.

Woo, David, 2003, In Search of "Capital Crunch": Supply Factors behind the Credit Slowdown in Japan, Journal of Money, Credit, and Banking, 35, 6.

Yoshino, Naoyuki and Mizoguchi, Tetsuro, 2011, Government Debt Issues in Comparison

between Japan and Greece: The Fiscal Policy Rule is Urgently Needed to Establish, Monetary

Monthly Report. 


\section{Appendix:}

Table 2: Quintile Groups in the EMU and Japan

\begin{tabular}{|c|c|c|}
\hline & Japan (1990) & EMU (2008) \\
\hline Quintile 1 & $\begin{array}{c}\text { Okinawa, Nara, Nagasaki, Kagoshima, Miyazaki, } \\
\text { Aomori, Kochi, Shimane, Akita, Saga }\end{array}$ & $\begin{array}{l}\text { Latvia, Slovak Republic, } \\
\text { Estonia }\end{array}$ \\
\hline Quintile 2 & $\begin{array}{l}\text { Tokushima, Iwate, Kumamoto, Wakayama, } \\
\text { Saitama, Ehime, Yamagata, Chiba, Oita, Tottori }\end{array}$ & $\begin{array}{l}\text { Greece, Portugal, } \\
\text { Slovenia, Malta }\end{array}$ \\
\hline Quintile 3 & $\begin{array}{l}\text { Hokkaido, Fukuoka, Fukushima, Gifu, Kagawa, } \\
\text { Miyagi, Niigata, Yamaguchi, Mie, Nagano }\end{array}$ & Spain, Italy, Cyprus \\
\hline Quintile 4 & $\begin{array}{l}\text { Yamanashi, Okayama, Hyogo, Kyoto, Ishikawa, } \\
\text { Fukui, Gunma, Ibaraki, Hiroshima, Kanagawa }\end{array}$ & $\begin{array}{l}\text { France, Germany, } \\
\text { Belgium, Austria }\end{array}$ \\
\hline Quintile 5 & $\begin{array}{c}\text { Toyama, Tochigi, Shizuoka, Shiga, Osaka, Aichi, } \\
\text { Tokyo }\end{array}$ & $\begin{array}{l}\text { Netherlands, Finland, } \\
\text { Ireland, Luxemburg }\end{array}$ \\
\hline
\end{tabular}

Ranked per capita GDP in 1990 in Japan and 2014 in EMU.

Table 3: Data Description

\begin{tabular}{|c|c|c|}
\hline Acronym & Description & Source \\
\hline GDP & Nominal GDP growth rate of prefecture $i$ in year $t$ & RSDB Japan \\
\hline LAT & $\begin{array}{l}\text { Changes in Local Allocation Tax grants and } \\
\text { national disbursements for prefecture i in year t }\end{array}$ & RSDB Japan \\
\hline Q5 & $\begin{array}{l}\text { Dummy variable: } 1 \text { for prefectures in the top } \\
\text { quintile with respect to GDP per capita in year } \\
\text { 1990, } 0 \text { if not. }\end{array}$ & RSDB Japan \\
\hline post90 & $\begin{array}{l}\text { Dummy variable: } 1 \text { if year is } 1990-2011,0 \text { if } \\
1976-1989\end{array}$ & RSDB Japan \\
\hline M0 & Control variable: changes in monetary base & Bank of Japan \\
\hline M1 & $\begin{array}{l}\text { Control variable: changes in monetary aggregate } \\
\text { M1 }\end{array}$ & Bank of Japan \\
\hline $\mathrm{GDP}_{\mathrm{t}-1}$ & $\begin{array}{l}\text { Control variable: changes in GDP of the previous } \\
\text { time period }\end{array}$ & RSDB Japan \\
\hline rich & $\begin{array}{l}\text { Control dummy variable: } 1 \text { for prefectures if their } \\
\text { GDP per capita in } 1990 \text { was equal or higher the } \\
\text { median GDP for all prefectures, } 0 \text { if not. }\end{array}$ & RSDB Japan \\
\hline
\end{tabular}


Table 4: Descriptive Statistics

\begin{tabular}{l|c|c|c|c|cc}
\hline Variable & Mean & Std. Dev. & Min & Max & \multicolumn{2}{c}{ Observations } \\
\hline GDP & 3.15 & 4.33 & -11.58 & 17.96 & $\mathrm{~N}=1692$ \\
\hline LAT & 3.04 & 14.41 & -39.13 & 346.28 & $\mathrm{~N}=1692$ \\
\hline M0 & 6.06 & 3.53 & 0.59 & 14.52 & $\mathrm{~N}=1692$ \\
\hline M1 & 6.56 & 5.00 & -0.51 & 27.60 & $\mathrm{~N}=1692$ \\
\hline GDP $_{\mathrm{t}-1}$ & 2.94 & 4.17 & -11.58 & 17.96 & $\mathrm{~N}=1645$ \\
\hline
\end{tabular}

Table 5: Unit Root Test Results

\begin{tabular}{l|c|c}
\hline Variable & Coefficient (Z-t-tilde-bar) & P-Value \\
\hline GDP & -11.4083 & 0.0000 \\
\hline LAT & -16.3102 & 0.0000 \\
\hline M0 & -7.7308 & 0.0000 \\
\hline M1 & -15.7383 & 0.0000 \\
\hline
\end{tabular}

Table 6: Wald Test Results for Joint-Significance

\begin{tabular}{c|c|c|c|c}
\hline Interaction term & $\begin{array}{c}\text { F-Score } \\
\text { Estimation 1 }\end{array}$ & $\begin{array}{c}\text { F-Score } \\
\text { Estimation 2 }\end{array}$ & $\begin{array}{c}\text { F-Score } \\
\text { Estimation 3 }\end{array}$ & $\begin{array}{c}\text { F-Score } \\
\text { Estimation4 }\end{array}$ \\
\hline$\beta_{1}+\beta_{2}$ & 0.0000 & 0.0000 & 0.0093 & 0.0000 \\
\hline$\beta_{1}+\beta_{4}$ & 0.0066 & 0.0392 & 0.0093 & 0.0335 \\
\hline$\beta_{1}+\beta_{2}+\beta_{3}+\beta_{4}$ & 0.0000 & 0.0000 & 0.0000 & 0.0000 \\
\hline$\beta_{3}+\beta_{4}$ & 0.0000 & 0.0000 & 0.0000 & 0.0000 \\
\hline
\end{tabular}

$\mathrm{H}_{0}=$ all terms combined are statistically indifferent from 0 . 